\title{
Analisa Profil Jabatan Dan Collective Self Esteem Pada Pencapaian Peak Performance Pegawai Negeri Sipil
}

\author{
Ilhamuddin, Yunda Megawati,\& Lusy Asa Akhrani \\ ilham@ub.ac.id
}

Program Studi Psikologi, FISIP, Universitas Brawijaya, Indonesia

\begin{abstract}
Penelitian ini bertujuan untuk mengetahui gambaran pencapaian peak performance, mengetahui tingkat pemahaman pegawai tentang profil jabatan mereka, mengetahui gambaran collective self esteem, serta mengetahui pengaruh profil jabatan dan collective self esteem terhadap pencapaian peak performance Pegawai Negeri Sipil di Lingkungan Pemerintah Kota Pasuruan. Sampel yang digunakan pada penelitian ini berjumlah 91 orang yang diambil dengan menggunakan teknik purposive sampling dengan ketentuan level jabatan staff, status PNS, sudah memiliki SK Pengangkatan, masa kerja minimal dua tahun, pendidikan minimal Sarjana Strata-1, dan usia produktif antara 21-55 tahun. Penentuan jumlah sampel menggunakan rumus Slovin dari 1000 orang jumlah populasi. Alat ukur yang digunakan pada penelitian ini adalah Skala Profil Jabatan yang disusun berdasarkan teori Landy dan Conte (2004), Skala Collective Self Esteem yang disusun berdasarkan teori Luthanen dan Crocker (1992), dan Skala Peak Performance yang disusun berdasarkan teori Landy dan Conte (2004). Analisis data hasil penelitian menggunakan uji hipotesis analisis regresi linier berganda, didapatkan hasil bahwa pegawai memiliki informasi profil jabatan yang rendah, collective self esteem yang rendah pula, sehingga tidak dapat mencapai peak performance dalam pekerjaan mereka.
\end{abstract}

Kata kunci: profil jabatan, collective self esteem, peak performance

Puncak kinerja seorang karyawan atau peak performance merupakan kemampuan individu untuk memberikan hasil kerja maksimal dari usaha tertinggi yang dilakukannya untuk mencapai level produktivitas tertentu. Profil jabatan akan menyajikan informasi tertulis yang menjadi acuan organisasi atau perusahaan dalam memilih dan menempatkan karyawan dengan kompetensi paling sesuai dengan tugas pekerjaan yang akan dilakukannya, sekaligus menjadi rujukan bagi karyawan untuk memahami tugas pekerjaan dan batasanbatasan dalam bekerja. Profil jabatan memuat deskripsi pekerjaan (job description) yang terdiri dari judul atau nama jabatan dan dalam departemen atau divisi apa seseorang bekerja, ringkasan tugas secara umum, deskripsi tugas, gambaran hirarki atau struktur organisasi yang secara tersirat terdapat dalam deskripsi tugas, wewenang karyawan, dan tanggung jawab kerja apa saja yang harus dilakukannya. Selain memuat job description profil jabatan juga menerangkan kemampuan-kemampuan apa saja yang dibutuhkan seorang karyawan untuk dapat melakukan tugas pekerjaan dengan baik atau memuat daftar kompetensi yang disebut sebagai job specification, yang 
menjadi dasar bagi perusahaan untuk mencantumkan prasyarat personal apa saja yang mampu memenuhi kualifikasi kompetensi tersebut, yang disebut dengan job requirement. Perusahaan yang menggunakan profil kompetensi sebagai acuan dalam melakukan kegiatan pengadaan karyawan, pengelolaan karyawan, dan pengembangan karyawan diharapkan mampu mendorong karyawan mencapai peak performance mereka dalam bekerja. Landy dan Conte (2004) menerangkan tentang analisis jabatan sebagai suatu proses yang menghasilkan informasi mengenai tugas atas jabatan tertentu, yang dapat dijadikan sebuah landasan bagi karyawan dalam melakukan tugas pekerjaannya yang disebut sebagai profil jabatan. Profil jabatan atau dengan kata lain uraian jabatan merupakan suatu uraian tentang pekerjaan yang diuraikan secara sederhana dengan mencantumkan: Daftar uraian jabatan dan tipe pekerjaan.

1. Kompetensi dan kemampuan yang dibutuhkan oleh karyawan untuk melakukan tugas tersebut.

2. Persyaratan jabatan yang dibutuhkan untuk mengisi pekerjaan tersebut yang menginformasikan tentang pendidikan, keterampilan, dan keahlian yang dimiliki oleh karyawan.

Sedangkan aspek sosial dan aspek organisasi yang menciptakan perasaan berharga individu dalam sebuat kelompok atau dalam jabatan organisasinya tersebut yang disebut sebagai collective self-esteem. Sebagaimana yang disebutkan oleh Luthanen dan Crocker (1992) menyebutkan skala collective self-esteem meliputi:

1. Harga diri anggota (membership selfesteem). Indikator ini mengacu pada penilaian seseorang tentang perbuatan baik dan layak dirinya sebagai anggota kelompok.

2. Harga diri pribadi (private collective selfesteem) yang berkaitan dengan bagaimana individu menilai kelompoknya.

3. Harga diri publik (public collective selfesteem), mengacu pada bagaimana non anggota kelompok (individu di luar kelompok) mengevaluasi dan menilai kelompoknya.

Pentingnya identitas kelompok (importance to identity), terkait dengan betapa pentingnya keanggotaan dalam sebuah kelompok sebagai identitas seseorang. Terdapat empat indikator collective selfesteem antara lain adalah harga diri anggota yang mengacu pada penilaian seseorang tentang perbuatan baik atau layak dirinya sebagai anggota kelompok (membership selfesteem), bagaimana individu menilai kelompoknya yang disebut sebagai harga diri pribadi (private collective self esteem), bagaimana penilaian individu di luar kelompok akan menilai kelompok tersebut (public collective self-esteem), dan betapa pentingnya keanggotaan dalam sebuah kelompok sebagai identitas seseorang Karyawan dengan collective self-esteem akan terdorong untuk menampilkan peak performance atas dasar integritas dan komitmennya terhadap tugas maupun perusahaan atau organisasi.

Mengacu pada profil jabatan yang telah dibuat dan ditujukan untuk meningkatkan keterlibatan kerja ataupun keterlibatan sosial setiap karyawan. Adanya profil jabatan yang mengatur pekerjaan setiap orang sesuai dengan kapasitas dan beban kerjanya diharapkan dapat membantu para staf PNS bekerja optimal, dan dengan acuan kerja serta sistem kerja yang lebih konduksif diharapkan 
staf PNS memiliki rasa bangga dan kepercayaan diri yang tinggi akan kemampuannya dalam melakukan tugas pekerjaannya sehingga motivasi internal yang timbul mampu membantu mereka mencapai performa puncak dalam bekerja. Landy dan Conte (2004) menerangkan tentang performa kerja sebagai sikap seorang karyawan yang sesuai dengan harapan tujuan organisasi, yang diukur berdasarkan kinerja yang dihasilkan oleh individu. Mengukur performa kerja dilakukan berdasarkan:

1. Waktu yang dibutuhkan untuk menyelesaikan tugas atau pekerjaan yang dibebankan kepada karyawan.

2. Jumlah/kuantitas kerja yang dihasilkan.

3. Presensi atau kehadiran karyawan yang menunjukkan keterlibatannya dalam bekerja.

4. Kualitas hasil kerja.

5. Produktivitas yang dicapai oleh perusahaan akibat kinerja individu.

Atas dasar latar belakang itulah, maka penelitian ini bertujuan melakukan kajian lebih lanjut tentang analisis profil jabatan dan collective self-esteem pada peak performance pada Pegawai Negeri Sipil.

\section{Metode \\ Desain}

Dalam penelitian ini, jenis penelitian yang dilakukan adalah metode deskriptif kuantitatif, yaitu jenis penelitian yang menggambarkan fenomena berdasarkan faktafakta/kejadian untuk kemudian diolah menjadi data dan selanjutnya dianalisis sehingga pada akhirnya menghasilkan suatu kesimpulan. Adapun analisis yang dilakukan adalah untuk mengetahui korelasi antar variabel. Variabel independen, yaitu variabel $\mathrm{X}$ yang dalam hal ini profil jabatan merupakan variabel $\mathrm{X} 1$ dan collective self esteem merupakan variabel $\mathrm{X} 2$ dan korelasinya dengan variabel dependen, yaitu variabel $\mathrm{Y}$, yang dalam penelitian ini adalah peak performance.

\section{Partisipan}

Populasi dalam penelitian ini adalah seluruh PNS di lingkungan Pemerintah Kota Pasuruan non-guru yang berjumlah 1.000 orang. Sampel dalam penelitian ini adalah PNS dengan level jabatan staf dengan status PNS dan sudah memiliki SK pengangkatan, masa kerja minimal 2 tahun, pendidikan minimal sarjana S-1, rentang usia 21-55 tahun. Teknik pengambilan sampel yang digunakan pada penelitian ini adalah nonprobability sampling. Metode pengambilan sample yang digunakan adalah purposive sampling. Teknik yang digunakan untuk menentukan jumlah sample menggunakan rumusan Slovin.

Berdasarkan perhitungan, dengan jumlah populasi sebanyak 1.000 orang, maka sampel yang digunakan pada penelitian ini berjumlah 91 orang dengan lokasi sampel tersebar di 20 SKPD, antara lain Bapeda, Bakesbanglinmas, Badan Pengelolaan Keuangan dan Aset, Badan Lingkungan Hidup, Badan Kepegawaian Daerah, Bapemas, Badan Pemberdayaan Perempuan dan KB, Dinas Pendidikan, Diskoperindag, Dispenda, Dinas PU, Dinas Kependudukan dan Capil, Dinas Sosial, Tenaga Kerja, dan Transmigrasi, Dinas Pemuda dan Olahraga, Sekretariat Daerah, Kantor Kecamatan Gadingrejo, Panggungrejo, Bugul Kidul, Kantor Arsip, Kantor Perpustakaan dan Dokumentasi.

\section{Instrumen Penelitian}

Pada penelitian ini peneliti menggunakan 3 skala, yaitu Skala Profil Jabatan, Skala 
Collective Self-Esteem, dan Skala Peak Performance. Tipe skala yang digunakan adalah skala Likert yang terdiri dari lima pilihan jawaban pada setiap butirnya. Skala penelitian berisi pernyataan-pernyataan dengan dua jenis aitem, yaitu favorable dan unfavorable.

Skala dalam penelitian ini disusun sendiri oleh peneliti dengan mengacu pada teori Landy dan Conte (2004) untuk Skala Profil Jabatan dan Peak Performance. Sedangkan skala Collective Self Esteem disusun dengan mengacu pada teori Luthanen dan Crocker (1992).

Kuesioner yang digunakan berupa multiple choice question dan bersifat tertutup dengan skala sikap berpedoman pada skala Likert. Responden diminta tanggapan atas pertanyaan-pertanyaan yang diberikan apakah setuju/tidak setuju ataukah memiliki kepentingan tinggi/rendah terhadap pernyataan yang diajukan.

\section{Analisis Data}

Data yang diperoleh dari penelitian lapangan diolah dengan pendekatan kuantitatif untuk dua tujuan yaitu, deskripsi statistik dan deskripsi hasil gambaran umum. Untuk mengetahui korelasi profil jabatan dan collective self-esteem dengan peak performance, maka data diolah dengan menganalisis sikap responden terhadap setiap butir kuesioner untuk melihat hasil penilaian positif atau negatif dengan menggunakan analisis Likert Summated Rating yang mengkategorisasikan sikap responden sebagai berikut:
Tabel 1.

Kategorisasi sikap responden.

\begin{tabular}{|c|c|c|c|}
\hline $\begin{array}{l}\text { Sangat } \\
\text { Negatif }\end{array}$ & Negatif & Positif & $\begin{array}{l}\text { Sangat } \\
\text { Positif }\end{array}$ \\
\hline $20 \%$ & $40 \%$ & $80 \%$ & $100 \%$ \\
\hline Maksimum & $\begin{array}{r}\mathrm{K} 1 \\
60 \\
\mathrm{Me}\end{array}$ & $\%$ & Maksimum \\
\hline
\end{tabular}

Nilai tiap batasan (minimum, kuartil 1, median, kuartil 3, dan maksimum) adalah hasil perkalian jumlah responden dengan jumlah butir pertanyaan untuk setiap subvariabel yang dianalisis serta batasan skala (1 untuk nilai minimal dan seterusnya 5 untuk nilai maksimal). Untuk menghitung skor ideal (kriterium), yaitu skor yang digunakan untuk menghitung skor untuk menentukan rating scale dan jumlah seluruh jawaban digunakan rumus berikut:

Skor kriterium $=$ Nilai skala $\mathrm{x}$ Jumlah responden

Selanjutnya, skor yang diperoleh kemudian dimasukkan ke dalam rating scale:

Tabel 2.

Rating scale.

\begin{tabular}{cc}
\hline Nilai Jawaban & Skala \\
\hline $81-100$ & Sangat Baik \\
$61-80$ & Baik \\
$41-60$ & Cukup \\
$21-40$ & Kurang \\
$0-20$ & Sangat Kurang \\
\hline
\end{tabular}

Sedangkan untuk mengetahui jumlah jawaban dari para responden melalui prosentase, yaitu digunakan rumus sebagai berikut: 


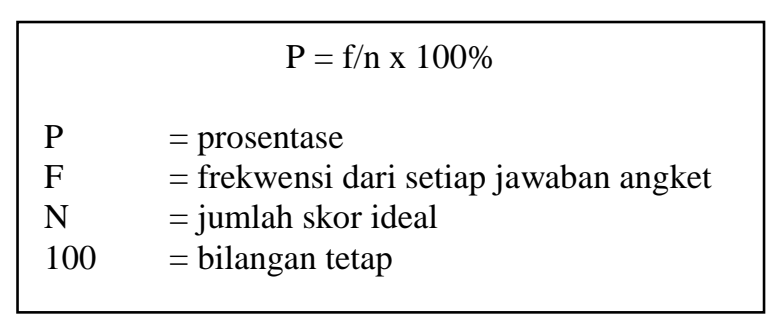

Selanjutnya untuk menentukan besaran pengaruh variabel Profil Jabatan (X1), Collective Self-Esteem (X2), terhadap Peak Performance $(\mathrm{Y})$, dilakukan analisis regresi berganda (multiple regression).

\section{Hasil}

Untuk menjelaskan hasil penelitian ini, secara umum terdapat dua penjelasan hasil penelitian, yaitu deskripsi hasil gambaran umum dan deskripsi statistik.

\section{Deskripsi Statistik}

Sebelum menjelaskan hasil uji regresi berganda atas data penelitian ini, penulis telah melakukan beberapa uji asumsi, yaitu autokorelasi, normalitas, linieritas, dan multikolineritas dengan hasil sebagai berikut:

a. Tidak terjadi autokorelasi antar variable dengan melihat luaran nilai DurbinWatson (DW) sebesar 2,15 dimana standarnya adalah $1<\mathrm{DW}<3$

b. Data terdistribusi secara normal

c. Uji linieritas terpenuhi dengan memperhatikan nilai signifikansi sebesar 0,149 dimana lebih besar dari 0,05 (sig > $0,05)$

d. Tidak terjadi multikolinieritas antar variabel bebas dengan memperhatikan nilai VIF $(1,036)$ lebih kecil dari 5.

Dengan terpenuhinya semua uji asumsi di atas maka pendekatan parametrik dengan regresi berganda dapat dilakukan. Adapun hasil uji regresi berganda dapat dilihat sebagai berikut:

\section{Deskripsi Hasil Gambaran Umum}

Berdasarkan analisis data yang dilakukan, maka dapat dijelaskan prosentase dari setiap skala:

a. Prosentase Skala Profil Jabatan

Tabel 3.

Prosentase Profil Jabatan.

\begin{tabular}{|c|c|}
\hline Indikator Profil Jabatan & $\%$ \\
\hline \multicolumn{2}{|l|}{$\begin{array}{l}\text { Job Description: Informasi tentang } \\
\text { uraian pekerjaan }\end{array}$} \\
\hline $\begin{array}{l}\text { 1. Sumber informasi mengenai } \\
\text { uraian pekerjaan }\end{array}$ & 13.44 \\
\hline $\begin{array}{l}\text { 2. Urgensi job description } \\
\text { menurut opini pegawai }\end{array}$ & 13.35 \\
\hline $\begin{array}{l}\text { 3. Keterlibatan pegawai dalam } \\
\text { penyusunan profil jabatan }\end{array}$ & 14.55 \\
\hline $\begin{array}{l}\text { 4. Informasi pokok dalam job } \\
\text { description }\end{array}$ & 12.42 \\
\hline $\begin{array}{l}\text { 5. Pemahaman akan keluaran } \\
\text { pekerjaan dan keseteraan } \\
\text { kompetensi }\end{array}$ & 13.75 \\
\hline $\begin{array}{l}\text { Job Specification: Kesesuaian antara } \\
\text { kemampuan berpikir, kemampuan } \\
\text { teknis, dan kapasitas kepribadian } \\
\text { dengan pekerjaan. }\end{array}$ & 19.11 \\
\hline $\begin{array}{l}\text { Job Requirement: Kesesuaian antara } \\
\text { prasyarat individu dengan tuntutan } \\
\text { pekerjaan, yang meliputi latar } \\
\text { belakang pendidikan dan pengalaman. }\end{array}$ & 12.42 \\
\hline
\end{tabular}

Sumber informasi mengenai job description sebesar $13.44 \%$ dari keseluruhan pengetahuan mengenai profil jabatan menunjukkan bahwa staf PNS Pemkot Pasuruan kurang memiliki sumber informasi tertulis mengenai uraian tugas pekerjaan mereka. Urgensi job description menurut opini pegawai sebesar $13.35 \%$ dari keseluruhan pengetahuan mengenai profil jabatan menunjukkan bahwa Staf PNS Pemkot Pasuruan kurang memandang penting 
adanya uraian pekerjaan secara tertulis bagi pekerjaan mereka.

Keterlibatan pegawai dalam penyusunan profil jabatan sebesar $14.55 \%$ keseluruhan pengetahuan mengenai profil jabatan menunjukkan bahwa staf PNS Pemkot Pasuruan memiliki minat yang rendah untuk berpartisipasi aktif dalam menyusun profil jabatan. Informasi pokok dalam job description sebesar $13.89 \%$ keseluruhan pengetahuan mengenai profil jabatan menunjukkan bahwa staf PNS Pemkot Pasuruan memiliki informasi yang rendah akan hal-hal pokok yang berkaitan dengan tugas mereka dalam melaksakan pekerjaan.

Pemahaman akan keluaran pekerjaan dan kesetaraan kompetensi sebesar $13.75 \%$ keseluruhan pengetahuan mengenai profile jabatan menunjukkan bahwa staf PNS Kota Pasuruan memiliki tingkat pemahaman yang rendah akan tujuan mereka melakukan tugas pekerjaannya, kriteria keluaran yang diharapkan dari pekerjaannya, dan keterampilan apa saja yang seharusnya mereka miliki untuk dapat mencapai keluaran yang diharapkan dari pekerjaannya. Kesesuaian antara kemampuan berpikir, kemampuan teknsi, dan kapasitas kepribadian dengan pekerjaan sebesar $19.11 \%$ keseluruhan pengetahuan mengenai profil jabatan menunjukkan bahwa pada dasarnya staf PNS Pemkot Pasuruan tidak memiliki kemampuan teknis dan kapasitas kepribadian yang sesuai dengan tuntutan pekerjaan mereka. Akan tetapi angka ini masih relative lebih tinggi dibanding pemahaman mereka akan job description.

Kesesuaian antara prasyarat individu dengan tuntutan pekerjaan yang meliputi latar belakang pendidikan dan pengalaman sebesar $12.42 \%$ keseluruhan pengetahuan mengenai profil jabatan yang berarti bahwa staf PNS
Pemkot Pasuruan tidak memiliki latar belakang pendidikan ataupun pengalaman yang sepenuhnya sesuai dengan bidang kerja dan tugas pekerjaan yang mereka lakukan saat ini.

\section{b. Prosentase Skala Collective Self-Esteem}

Sedangkan hasil Analisis Skala Collective Self Esteem adalah sebagai berikut:

Tabel 4.

Prosentase Collective Self-Esteem.

\begin{tabular}{clc}
\hline No. & \multicolumn{1}{c}{$\begin{array}{c}\text { Indikator Collective Self } \\
\text { Esteem }\end{array}$} & $\%$ \\
\hline 1 & Harga diri anggota & 27.54 \\
2 & Harga diri pribadi & 27.86 \\
3 & Harga diri public & 23.28 \\
4 & Harga diri kelompok & 24.26 \\
\hline
\end{tabular}

Kontribusi faktor harga diri anggota. Bahwa dasar pertimbangan individu memberi kontribusi sebesar $27.54 \%$ untuk melakukan perbuatan baik. Faktor harga diri pribadi. Pertimbangan peran memberi kontribusi sebesar $27.86 \%$ untuk melakukan perbuatan yang diharapkan oleh kelompoknya. Faktor akan harga diri publik dasar pertimbangan penilaian pegawai itu sendiri akan pendapat orang lain atas tugas pekerjaannya memberikan kontribusi sebesar $23.28 \%$ untuk mendorong individu melakukan perbuatan baik dalam pekerjaannya. Tingginya faktor akan harga diri dasar pertimbangan penilaian pegawai akan tugas pekerjaannya sebagai label atau sarana peningkatan harga dirinya memberikan kontribusi sebesar $24.26 \%$ untuk mendorong pegawai melakukan perbuatan yang diharapkan oleh kelompoknya. 


\section{c. Hasil Analisis Skala Peak Performance}

Tabel 5.

Prosentase Peak Performance.

\begin{tabular}{clc}
\hline No. & Indikator Peak Performance & $\%$ \\
\hline 1 & $\begin{array}{l}\text { Kesesuaian antara kualifikasi } \\
\text { administratif dengan tugas } \\
\text { pekerjaan. }\end{array}$ & 12.39 \\
2 & Tingkat kedisplinan karyawan & 11.94 \\
3 & Tingkat komitmen kerja & 13.14 \\
4 & Kemampuan bekerja dalam & 13.35 \\
& kelompok & 12.66 \\
5 & Kompetensi softskill individu & 13.14 \\
6 & Kemampuan komunikasi & 11.66 \\
7 & Kemampuan kepemimpinan & 10.72 \\
\hline 8 & Perencanaan kerja &
\end{tabular}

Tingkat kesesuaian antara kualifikasi administratif dengan tugas pekerjaan sebesar $12.39 \%$ dari indikator keseluruhan pencapaian peak performance, yang berarti bahwa pegawai kurang memahami persyaratan administratif yang harus dimiliki untuk dapat mencapai performa puncak dalam pekerjaannya. Tingkat kedisiplinan pegawai sebesar $11.94 \%$ dari indikator keseluruhan pencapaian peak performance, sehingga dapat dikatakan bahwa karyawan kurang memiliki kedisiplinan untuk dapat mencapai performa puncak dalam pekerjaannya. Tingkat kemampuan bekerja dalam kelompok sebesar $13.14 \%$ dari indikator keseluruhan pencapaian peak performance, sehingga dapat dikatakan bahwa karyawan kurang memiliki komitmen dalam bekerja untuk dapat mencapai performa puncak dalam pekerjaannya.

Tingkat kemampuan bekerja sama dalam kelompok sebesar $13.35 \%$ dari indikator keseluruhan pencapaian peak performance, sehingga dapat dikatakan bahwa karyawan kurang memiliki koordinasi yang efektif antar individu dalam bidang kerjanya untuk dapat mencapai performa puncak dalam pekerjaannya, atau dengan kata lain karyawan cenderung bekerja berdasarkan instruksi disbanding kesadarannya untuk saling menunjang kinerja satu sama lain. Tingkat kompetensi softskill individu sebesar $12.66 \%$ dari indikator keseluruhan pencapaian peak performance, sehingga dapat dikatakan bahwa softskill karyawan yaitu kompetensi penunjang kinerja masih kurang untuk dapat mencapai performa puncak dalam pekerjaannya. Tingkat komunikasi sebesar $13.14 \%$ dari indikator keseluruhan pencapaian peak performance, sehingga dapat dikatakan bahwa keterampilan komunikasi yang dimiliki pegawai kurang menunjang untuk dapat mencapai performa puncak dalam pekerjaannya. Tingkat kepemimpinan sebesar $11.66 \%$ dari indikator keseluruhan pencapaian peak performance, sehingga dapat dikatakan bahwa pegawai kurang memiliki kemampuan kepemimpinan bagi dirinya sendiri dan bagi orang lain untuk dapat mencapai performa puncak dalam pekerjaannya.

Tingkat perencanaan kerja sebesar $10.72 \%$ dari indikator keseluruhan pencapaian peak performance, sehingga dapat dikatakan bahwa karyawan kurang memiliki perencanaan kerja atas dasar kemampuan dan inisiatifnya sendiri dalam menyusun prioritas kerja untuk dapat mencapai performa puncak dalam pekerjaannya. Adapun gambaran profil jabatan dan gambaran collective self-esteem pada pencapaian peak performance pegawai adalah:

Tabel 6.

Korelasi Antar Variabel Penelitian.

\begin{tabular}{lcc}
\hline & Profil Jabatan & $\begin{array}{c}\text { Collective Self - } \\
\text { Esteem } \\
(\mathrm{Pyx} 2)\end{array}$ \\
\hline Peak Performance & 0.899 & 0.879 \\
\hline
\end{tabular}

Profil jabatan mempengaruhi pencapaian performa puncak kinerja pegawai sebesar 0.899. Collective Self-Esteem mempengaruhi pencapaian performa puncak kinerja pegawai sebesar

0.879 . 


\section{Diskusi}

Profil jabatan menurut Landy dan Conte (2004) adalah informasi mengenai tugas atas jabatan tertentu, yang dapat dijadikan sebuah landasan bagi karyawan dalam melakukan tugas pekerjaannya. Profil jabatan yang ideal minimal memuat uraian tentang pekerjaan yang diuraikan secara sederhana dengan mencantumkan:

1. Daftar uraian jabatan dan tipe pekerjaan.

2. Kompetensi dan kemampuan yang dibutuhkan oleh karyawan untuk melakukan tugas tersebut.

3. Persyaratan jabatan yang dibutuhkan untuk mengisi pekerjaan tersebut yang menginformasikan tentang pendidikan, keterampilan, dan keahlian yang dimiliki oleh karyawan.

Berdasarkan penjelasan mengenai profil jabatan, dapat disimpulkan bahwa profil jabatan merupakan uraian tertulis mengenai tugas pekerjaan yang dilakukan oleh pegawai yang berfungsi sebagai acuan mereka dalam bekerja, agar pegawai mengetaui keluaran (output) yang diharapkan dari pekerjaan mereka, dan agar pegawai mengetahui kompetensi atau kemampuan apa saja yang harus mereka miliki dalam rangka mencapai sasaran pekerjaan yang diharapkan.

Hasil penelitian yang dilakukan kepada 91 PNS yang berada pada level jabatan staf yang tersebar dalam 20 SKPD menunjukkan bahwa informasi mengenai profil jabatan dalam pekerjaan mereka sangat rendah. Dapat disimpulkan mengenai gambaran pegawai berkaitan dengan profil jabatan atas pekerjaannya adalah:

1. Informasi dan pengetahuan mereka tentang pekerjaannya, luaran-luaran yang diharapkan dari pekerjaannya, pandangan dan kemauan mereka untuk memiliki profil jabatan tertulis secara ideal masih sangat rendah.

2. Pegawai tidak selalu bekerja sesuai dengan latar belakang pendidikan dan pengalaman yang mereka miliki.

3. Kesesuaian antara keterampilan teknis maupun non teknis yang dimiliki oleh pegawai sehubungan dengan tugas pekerjaan mereka sangat rendah.

Sedangkan collective self-esteem PNS Pemkot Pasuruan yang berada pada level jabatan staf, yaitu perasaan berharga individu dalam sebuah kelompok, baik kelompok dalam lingkup kecil yaitu kelompok bidang kerjanya ataupun kelompok dalam lingkup dinas atau SKPD maupun kelompok dalam arti sebagai PNS Pemkot Pasuruan secara luas, dapat digambarkan sebagai berikutbahwa gambaran collective self-esteem pegawai yang cenderung rendah diartikan bahwa penilaian yang bersumber pada harga diri, baik itu harga diri yang timbul secara instrinsik ataupun ekstrinsik bukan merupakan hal utama yang membuat pegawai bersikap positif ataupun negative atas pekerjaannya. Peran kebijakan, aturan, dan supervisi atasan yang bersifat aktual dan objektif penting untuk dapat membentuk sikap dan perilaku kerja karyawan.

Berdasarkan gambaran informasi mengenai profil jabatan dan collective self-esteem pegawai, maka diperoleh gambaran yang relevan tentang peak performance pegawai dan keterkaitan diantaranya. Peak performance atau kinerja puncak merupakan sikap individu yang mampu mencapai tujuan dan harapan organisasi dalam pekerjaannya dengan bekerja menggunakan prinsip efektivitas. Berdasarkan karakteristik peak performance tersebut memang seluruhnya belum tercapai secara optimal, sehingga 
performa kerja PNS Pemkot Pasuruan pada level jabatan staf berdasarkan peringkat yang dikemukakan oleh Dharma (2004) adalah berada pada peringkat kedua, yaitu peringkat yang masih dasar di mana kinerja pegawai tidak memenuhi semua syarat pokok performa kerja optimal yang ditetapkan untuk melaksanakan suatu tugas. Akan tetapi, pada dasarnya pegawai dengan tingkat kinerja ini dapat memenuhi kriteria tugas dalam satu tugas atau lebih bidang pokok. Namun, kinerjanya dapat meningkat dan diperkirakan dapat mencapai tingkat yang benar-benar memuaskan karena adanya aspek potensial dari dalam dirinya.

Oleh karena itu, dibutuhkan profil jabatan untuk mengarahkan pegawai akan masukan dan keluaran yang jelas dari pekerjaannya, serta dibutuhkan pembentukan collective selfesteem agar penilaian akan harga diri dalam kelompok membentuk keterikatan yang kuat. Adanya tugas yang jelas dan keterikatan yang kuat membuat karyawan menempatkan dirinya pada level kinerja yang diharapkan. Apabila level tersebut belum tercapai, maka diharapkan dapat menstimulasi kemauan dan kemampuan belajar pegawai. Akan tetapi gambaran aktualnya saat ini adalah tingkat informasi profil jabatan yang rendah serta collective self-esteem yang rendah tentu saja mempengaruhi performa kerja yang dihasilkan oleh pegawai.

Dapat dijelaskan bahwa tingkat keterkaitan antara profil jabatan dan pencapaian peak performance berada pada kategori sangat tinggi. Sementara itu, Collective self-esteem dan pencapaian peakperformance berada pada kategori sangat tinggi. Dengan kata lain, dapat disimpulkan bahwa pencapaian performa puncak kinerja karyawan dipengaruhi oleh faktor profil jabatan dan adanya collective self-esteem pada setiap pegawai. Profil jabatan yang tidak tersedia secara akurat dan lengkap (ketersediaan rendah) akan mempengaruhi tingkat performa kerja karyawan yang rendah pula untuk halhal yang berhubungan dengan kemampuan teknis dalam bekerja. Sedangkan collective self-esstem rendah yang dimiliki oleh pegawai akan mempengaruhi rendahnya pula tingkat pencapaian performa puncak kinerja pegawai dalam hal kemampuan non teknis (softskill) dalam pekerjaannya.

Berdasarkan hasil penelitian di atas, maka saran pengembangan yang dapat diberikan adalah sebagai berikut: (1) menerapkan kinerja berdasarkan evaluasi jabatan dan mengacu pada profil jabatan sebagai basis informasi pekerjaan yang akurat sehingga diharapkan dapat menjadi acuan untuk mencapai kinerja Pegawai Negeri Sipil yang berbasis pada good corporate governance, (2) adanya kinerja berbasis pada profil jabatan akan dapat dibedakan antara pegawai yang good performer dan bad performer yang tentunya berpengaruh terhadap pemberian kompensasi secara tepat, adil, dan dapat dipertanggungjawabkan.

Pemerataan dan pelaksanaan promosi, mutasi, demosi dan pengembangan Pegawai Negeri Sipil yang berbasis pada prinsip pemerataan dan keadilan berdasarkan acuan yang obyektif melalui profil jabatan sebagai landasan dalam melakukan penilaian kinerja pegawai.

Baseline analisis terhadap pengembangan potensi produktivitas Pegawai Negeri Sipil yang digambarkan melalui peak performance dapat ditindaklanjuti dengan pemberian pelatihan pegawai yang tidak hanya berorientasi pada peningkatan keterampilan teknis yang berhubungan dengan tugas pekerjaan, namun juga pelatihan dengan 
sasaran pembentukan perilaku penunjang kinerja (softskill) pada level jabatan staf.

Menumbuhkan collective self esteem dan pencitraan positif atas kinerja Pegawai Negeri Sipil dengan adanya gathering dan kick-off tentang budaya kerja secara berkala dan konsisten, selain itu perlu memperhatikan sistem dan jangka waktu mutasi pegawai, agar pegawai memiliki pencitraan positif terhadap kelompok bidang kerja maupun SKPD-nya karena adanya keterikatan dengan kelompoknya.

\section{Kesimpulan}

Berdasarkan hasil penelitian yang dilakukan, maka diperoleh gambaran aktual PNS Pemkot Pasuruan pada level jabatan staf bahwa informasi dan pengetahuan mereka tentang pekerjaannya, luaran-luaran yang diharapkan dari pekerjaannya, serta pandangan dan kemauan mereka untuk memiliki profil jabatan tertulis secara ideal masih sangat rendah. Pegawai juga tidak selalu bekerja sesuai dengan latar belakang pendidikan dan pengalaman yang mereka miliki, sehingga kesesuaian antara keterampilan teknis maupun non-teknis yang dimiliki oleh pegawai sehubungan dengan tugas pekerjaan mereka sangat rendah.

Gambaran collective self-esteem pegawai yang cenderung rendah dapat diartikan bahwa penilaian yang bersumber pada harga diri, baik itu harga diri yang timbul secara instrinsik ataupun ekstrinsik bukan merupakan hal utama yang membuat pegawai bersikap positif ataupun negatif atas pekerjaannya. Peak performance juga dinilai masih belum tercapai secara optimal, sehingga performa kerja PNS Pemkot Pasuruan pada level jabatan staf berdasarkan peringkat yang dikemukakan oleh Dharma (2004) adalah berada pada peringkat kedua, yaitu peringkat yang masih dasar di mana kinerja pegawai tidak memenuhi semua syarat pokok performa kerja optimal yang ditetapkan untuk melaksanakan suatu tugas.

Secara umum, dapat disimpulkan bahwa tingkat informasi profil jabatan yang rendah serta collective self-esteem yang rendah tentu saja mempengaruhi performa kerja yang tidak mencapai peak performance yang diharapkan dari pegawai.

\section{Daftar Pustaka}

Dharma, A. (2004). Manajemen Supervisi. Jakarta: Rajawali Press.

Landy, F. J. \& Conte, J. M. (2004). Work in the $21^{\text {st }}$ Century, New York: McGraw Hill.

Milcovich, G. T. \& Bouedreau, J. W. (1997). Human Resource Management. Dubuque: Times Mirror Higher Education Group.

Robbins, S. P. (2001). Organizational Behavior. New Jersey: Prentice Hall Inc. 